\title{
Toll-Like Receptor 7
}

National Cancer Institute

\section{Source}

National Cancer Institute. Toll-Like Receptor 7. NCI Thesaurus. Code C30108.

Toll-like receptor 7 (1049 aa, $\sim 121 \mathrm{kDa}$ ) is encoded by the human TLR7 gene. This protein plays a role in the response to single-stranded RNA. 